\title{
The rearrangement of 3-nitropyridinium salts to 3-nitropyrroles
}

\author{
Anna K. Kuratova, Larisa V. Glyzdinskaya, Marina A. Vorontsova, \\ and Galina P. Sagitullina* \\ Department of Organic Chemistry, Omsk F.M. Dostoevsky State University, 55a Mira Ave, \\ 644077 Omsk, Russian Federation \\ sagitullina@chemomsu.ru
}

DOI: https://doi.org/10.24820/ark.5550190.p009.810

\begin{abstract}
The rearrangement of 3-benzoylamino-5-nitropyridinium quaternary salts by ethanolic methylamine results in the formation of 2-acyl-4-nitropyrroles.
\end{abstract}

Keywords: Nitropyrroles, rearrangement, pyridinium salts, aminopyridines

\section{Introduction}

The reaction of nucleophilic opening of a pyridine ring and recyclization of an acyclic intermediate to a pyrrole ring has been known for a long time. ${ }^{1,2}$ Rearrangements of substituted 3-amino-2bromopyridine, 2-bromo-3-hydroxypyridine, 2- and 3-pyridylnitrenes, pyridine $\mathrm{N}$-oxides and $\mathrm{N}$ alkyl-2,4,6-triphenylpyridinium salts to pyrroles have been reported. ${ }^{3}$

The rearrangement of 3-amino-2-bromopyridine into 3-cyanopyrrole under the action of potassium amide in liquid ammonia was the first example of the recyclization of a pyridine ring to a pyrrole. The pyrrole ring of 3-cyanopyrrole is formed from an acyclic intermediate formed after breaking pyridine ring $\mathrm{C} 2-\mathrm{C} 3$ bond. In the same conditions the rearrangement of 3-amino-2,6dibromo-, 3-amino-2-bromo-6-chloro- and 3-amino-2-bromo-6-ethoxypyridine results in 2-cyanoand 3-cyanopyrrole. The formation of 2-cyanopyrrole comes from breaking the $\mathrm{C} 3-\mathrm{C} 4$ bond of the pyridine ring. ${ }^{4-6}$

The rearrangement of 2-bromo-3-hydroxy-, 2,6-dibromo-3-hydroxy-, 2-bromo-5-ethoxy-3hydroxy- and 2,6-dibromo-5-ethoxy-3-hydroxypyridine by the action of potassium amide in liquid ammonia is completed with formation of pyrrole-2-carboxamides. The reaction involves breaking the pyridine $\mathrm{C} 3-\mathrm{C} 4$ bond with formation of a cyclic ketoketene, which produces pyrrole-2carboxamides by ammonolysis. ${ }^{6,7}$

2-Pyridyl- and 3-pyridylnitrenes, generated by the thermolysis (or by the flash vacuum thermolysis, FVT) of triazolo[4,5-b]- and triazolo[4,5-c]pyridines, 2-azidopyridine, tetrazolo[1,5- 
a]pyridines and [1,2,4]oxadiazolo[2,3-a]pyridin-2-one rearrange into 2- and 3-cyanopyrroles. 2-Cyanopyrrole formation is a result of consecutive 2-pyridylnitrene ring expansion and contraction. This mechanism was established by means of ${ }^{15} \mathrm{~N}$-labeling experiments. The label is equally distributed between the ring nitrogen atom and the nitrogen atom of the cyano group in the cyanopyrrole. $^{8-12}$ This reaction covers a wide range of the monocyclic and condensed hetarylnitrenes capable of the azine heterocyclic ring contraction rearrangement. ${ }^{13}$

Thermolysis of substituted (4-methyl-, 5-methyl-, 6-methyl- and 5-chloro-) and unsubstituted 2-azidopyridine $\mathrm{N}$-oxides results in the formation of 2-cyano-1-hydroxypyrroles. ${ }^{14,15}$ 2-Cyano-4nitropyrrole is formed when heating the 2-azido-5-nitropyridine 1-oxide in benzene. ${ }^{15}$

The rearrangement of a pyridine ring into a pyrrole ring occurs by photolysis of unsubstituted, methyl- and phenyl-substituted pyridine $N$-oxides, and 2-acylpyrroles are the reaction products. 16-21 The isomerization of these pyridine $N$-oxides to 2 -acylpyrroles proceeds through stages of oxaziridine formation, its valence tautomerization into the seven-membered 1,2-oxazepine ring and a [1.3]-sigmatropic shift. An alternative mechanism proposed for 2-acylpyrrole formation includes oxaziridine isomerization to an acyclic nitrene and nitrene addition to the carbon-carbon double bond. ${ }^{16-21}$ The rearrangement of 2,6-dicyanopyridine $\mathrm{N}$-oxide to 5-cyanopyrrole-2carbonyl cyanide occurs under irradiation following a similar scheme. ${ }^{22}$

Substituted $N$-alkyl(aryl)-2-benzoyl-3,5-diphenylpyrroles were formed by oxidation of $N$ alkyl(aryl)-2,4,6-triphenylpyridinium salts with potassium ferricyanide under alkaline conditions. $^{23,24}$

In all the examples of pyridine into pyrrole transformations listed here the source of the nitrogen atom in the pyrrole ring is the endocyclic nitrogen atom of the pyridine ring.

Nitropyrroles are important intermediate products in the synthesis of natural compounds, antitumor oligopeptides, as heterodienophiles in the Diels-Alder reaction, and in the synthesis of oligonucleotide primers and peptide-nucleic acids. ${ }^{25-29}$

The extraordinary biological and synthetic significance of compounds of the pyrrole series is a powerful stimulus to motivation the development of new approaches to the synthesis of these compounds. ${ }^{30-34}$ In this paper we present novel results of our investigations of the nitropyridinium salt rearrangement to 2-acyl-4-nitropyrroles.

\section{Results and Discussion}

The known examples of rearrangement of 3-carbamoyl and 3-cyanopyridinium salts occur with participation of the substituent upon formation of new pyridine ring. ${ }^{35-37}$ On the basis of data received, we supposed the possibility of rearrangement of 3-benzoylamino-5-nitropyridinium salts 3 to 2-acyl-4-nitropyrroles 4 . This idea we confirmed by experiment. Earlier, we published the first and only example of rearrangement of a quaternary 3-benzoylamino-5-nitrocollidinium salt to 2-acetyl-3,5-dimethyl-4-nitropyrrole. ${ }^{38}$ We returned to this reaction after developing a 
convenient method of synthesis of the initial 3-amino-5-nitropyridines $\mathbf{1}$, which were previously unknown. ${ }^{39}$

The starting 3-benzoylamino-5-nitropyridines 2 were synthesized by benzoylation (SchottenBaumann reaction) of 3-amino-5-nitropyridines 1 with benzoyl chloride (Table 1). Nitropyridines 1 were obtained from nitronicotinamide by a modified Hofmann rearrangement reaction using $\mathrm{PhI}(\mathrm{OAc})_{2}{ }^{39}$

Table 1. Preparation of 3-(benzoylamino)-5-nitropyridines $\mathbf{2}^{a}$<smiles>[R]c1nc([R])c(N)c([N+](=O)[O-])c1[R]</smiles>

1<smiles>[R]c1nc([R7])c([N+](=O)[O-])c([R])c1NC(=O)c1ccccc1</smiles>

2

\begin{tabular}{ccccccc}
\hline Entry & Starting material & $\mathrm{R}^{1}$ & $\mathrm{R}^{2}$ & $\mathrm{R}^{3}$ & Product & Yield \% $^{b}$ \\
\hline 1 & $\mathbf{1 a}$ & $\mathrm{Me}$ & $\mathrm{Me}$ & $\mathrm{H}$ & $\mathbf{2 a}$ & 92 \\
2 & $\mathbf{1 b}$ & $\mathrm{H}$ & $\mathrm{H}$ & $\mathrm{Ph}$ & $\mathbf{2 b}$ & 81 \\
3 & $\mathbf{1 c}$ & $\mathrm{Me}$ & $\mathrm{H}$ & $\mathrm{Ph}$ & $\mathbf{2 c}$ & 85 \\
4 & $\mathbf{1 d}$ & $\mathrm{Me}$ & $\mathrm{Ph}$ & $\mathrm{Me}$ & $\mathbf{2 d}$ & 82 \\
5 & $\mathbf{1 e}$ & $\mathrm{Me}$ & $\mathrm{Ph}$ & $\mathrm{Ph}$ & $\mathbf{2 e}$ & 95 \\
\hline
\end{tabular}

${ }^{a}$ Reaction conditions: 3 -aminopyridine $(7 \mathrm{mmol}), \mathrm{BzCl}(7.7 \mathrm{mmol})$, pyridine $(5 \mathrm{~mL}), 2 \mathrm{~h}, 0{ }^{\circ} \mathrm{C}$ to rt. ${ }^{b}$ Isolated and purified compounds.

The necessary pyridinium salts 3a-e were obtained by alkylation of pyridines 2a-e with dimethyl sulfate and methyl fluorosulfonate. Hygroscopic pyridinium methyl sulfates were transformed into the less-soluble pyridinium perchlorates $\mathbf{3}$ by replacement of the methyl sulfate anion to perchlorate (Table 2).

The rearrangement of pyridinium salts $\mathbf{3}$ under the action of methylamine solution in ethanol results in 2-acylpyrroles 4 as the main product of reaction. The side (minor) rearrangement products are substituted nitrobenzenes $\mathbf{5}$, which were isolated in trace amounts (Table 3 ).

The rearrangement of pyridinium salts $\mathbf{3}$ to pyrroles $\mathbf{4}$ occurs by addition of methylamine at position 2 of the pyridinium salt $\mathbf{3}$ to form a 1,2-dihydropyridine $\mathbf{A}$, followed by its isomerization to the open form $\mathbf{B}$. Bond rotation and cyclization of open form $\mathbf{C}$ to pyrrole ring is the result of interaction of amide anion and electrophilic carbon atom of Schiff base (nitrogen analogue of a carbonyl group). The rotation around $\mathrm{C} 3-\mathrm{C} 4$ bond, which results in spatial closure of nucleophilic and electrophilic centers in open form $\mathbf{C}$, precedes the stage of formation $\mathrm{C}-\mathrm{N}$ bond in pyrrole (Scheme 1). 
Table 2. Preparation of $N$-methylpyridinium salts 3<smiles>[R]c1nc([R])c([N+](=O)[O-])c([R])c1NC=O</smiles>

2<smiles>[R]c1c(NC(=O)OCC(=O)OC)c([R])[n+](C)c([R])c1[N+](=O)[O-]</smiles>

3

\begin{tabular}{ccccccccccc}
\hline Entry & $\begin{array}{c}\text { Starting } \\
\text { material }\end{array}$ & $\mathrm{R}^{1}$ & $\mathrm{R}^{2}$ & $\mathrm{R}^{3}$ & Product & Method $^{\mathrm{a}}$ & $\begin{array}{c}\text { Time } \\
(\mathrm{h})\end{array}$ & $\begin{array}{c}\mathrm{T}, \\
{ }^{\circ} \mathrm{C}\end{array}$ & Anion $^{\mathrm{b}}$ & $\begin{array}{c}\text { Yield } \\
\% \%^{\mathrm{c}}\end{array}$ \\
\hline 1 & $\mathbf{2 a}$ & $\mathrm{Me}$ & $\mathrm{Me}$ & $\mathrm{H}$ & $\mathbf{3 a}$ & $\mathrm{A}$ & 4 & 80 & $\mathrm{MeSO}_{4}$ & 89 \\
2 & $\mathbf{2 b}$ & $\mathrm{H}$ & $\mathrm{H}$ & $\mathrm{Ph}$ & $\mathbf{3 b}$ & $\mathrm{A}$ & 5 & 100 & $\mathrm{ClO}_{4}$ & 92 \\
3 & $\mathbf{2 c}$ & $\mathrm{Me}$ & $\mathrm{H}$ & $\mathrm{Ph}$ & $\mathbf{3 c}$ & $\mathrm{B}$ & 120 & $\mathrm{rt}$ & $\mathrm{SO}_{3} \mathrm{~F}$ & 90 \\
4 & $\mathbf{2 d}$ & $\mathrm{Me}$ & $\mathrm{Ph}$ & $\mathrm{Me}$ & $\mathbf{3 d}$ & $\mathrm{A}$ & 48 & 80 & $\mathrm{ClO}_{4}$ & 85 \\
5 & $\mathbf{2 e}$ & $\mathrm{Me}$ & $\mathrm{Ph}$ & $\mathrm{Ph}$ & $\mathbf{3 e}$ & $\mathrm{A}$ & 96 & 100 & $\mathrm{ClO}_{4}$ & 70 \\
\hline
\end{tabular}

a Method A: 3-(benzoylamino)pyridine (1 mmol), $\mathrm{Me}_{2} \mathrm{SO}_{4}(3 \mathrm{mmol})$, heat, then $\mathrm{NaClO}_{4}(1.1 \mathrm{mmol})$. Method B: 3-(benzoylamino)pyridine (5 mmol), $\mathrm{MeSO}_{3} \mathrm{~F}(15 \mathrm{mmol}), \mathrm{PhCl}(18 \mathrm{~mL}), 120 \mathrm{~h}$, rt. b 3-(Benzoylamino)pyridinium methylsulfate 3a is non-hygroscopic ${ }^{\mathrm{c}}$ Isolated and purified compounds

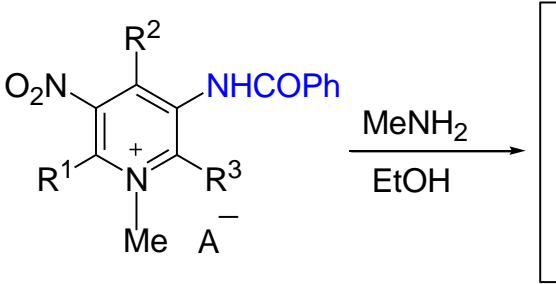

3

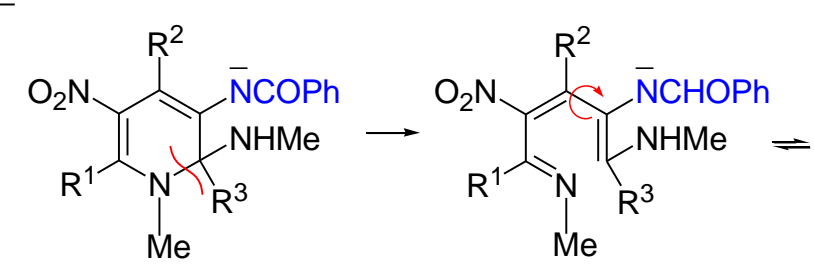

A

B<smiles>[R]C(NC)=C1CN(C)C(=O)C([N+](=O)[O-])=C1[R]</smiles>

C

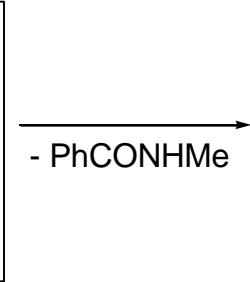

$X=0, N$

Scheme 1. Possible mechanism for the formation of nitropyrroles 4. 
Table 3. Rearrangement of $N$-methylpyridinium salts 3 by $30 \% \mathrm{MeNH}_{2}$ solution in ethanol ${ }^{a}$ (Method A)<smiles>[R]c1c(NC(=O)c2ccccc2)c([R])[n+](C)c([R])c1[N+](=O)[O-]</smiles>

3

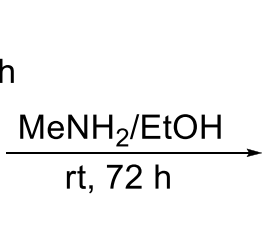<smiles>[R]c1[nH]c(C([X])[R])c([R])c1[N+](=O)[O-]</smiles>

$X=O, N M e$<smiles>[R]c1cc(NC(=O)c2ccccc2)c([R])c([N+](=O)[O-])c1[R]</smiles>

5

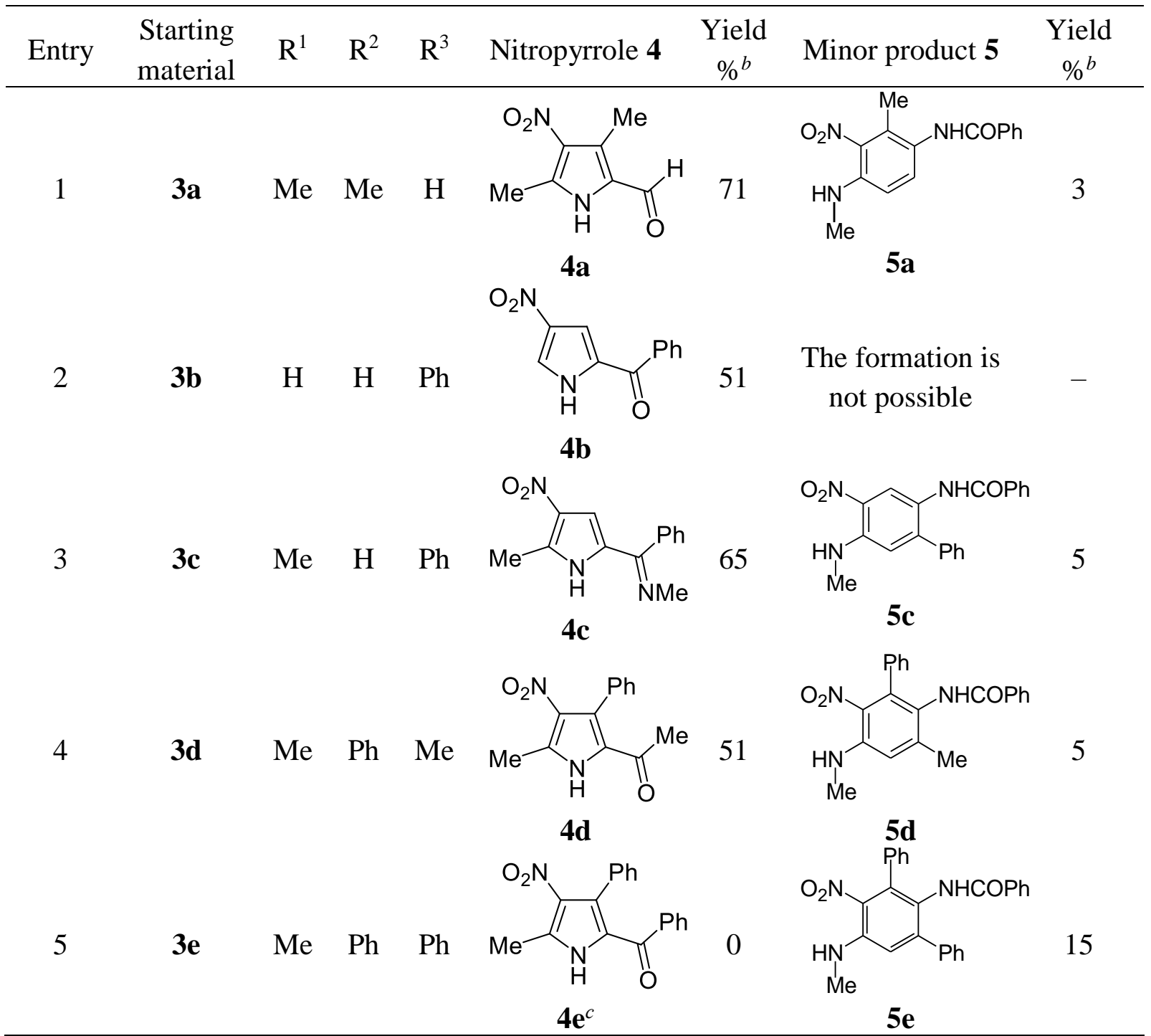

${ }^{a}$ Reaction conditions: $N$-methylpyridinium salts ( $\left.1 \mathrm{mmol}\right), 30 \% \mathrm{MeNH}_{2}$ in ethanol $(20 \mathrm{~mL}), 72 \mathrm{~h}$, rt. $\quad{ }^{b}$ Isolated and purified compounds. ${ }^{c}$ Not determined.

The rearrangement of 2,4-diphenyl-5-nitropyridinium salt $\mathbf{3 e}$ in the same conditions is accompanied by strong reaction mixture resinification and results in only benzene 5e formation, 
pyrrole 4e was not found in the reaction mixture. It is likely to be connected with influence of steric factors, determined by a large difference in size of substituents $(\mathrm{Ph}>>\mathrm{Me})$. The rotation around $\mathrm{C} 3-\mathrm{C} 4$ bond in open form $\mathbf{B}\left(\mathrm{R}^{2}=\mathrm{R}^{3}=\mathrm{Ph}\right)$ necessary to close pyrrole ring does not occur (Table 3, Scheme 1).

It was established on the example of 3-benzoylamino-5-nitro-4-phenyl-2,6-dimethyl pyridinium salt 3d, that in ethanolic methylamine solution the rearrangement proceeds with maximum pyrrole 4d yield. The replacement of ethanolic methylamine solution by aqueous solution significantly decreases nitropyrrole $\mathbf{4 d}$ yield and increases the proportion of methylaminobiphenyl 5d. Further decrease of pyrrole $\mathbf{4 d}$ yield and increase in that of methylaminobiphenyl 5d occurs when the reaction proceeds under the action of aqueous dimethylamine solution. The rearrangement of salt $\mathbf{3 d}$ in aqueous ethanolic $\mathrm{NaOH}$ solution occurs specifically with formation of only methylaminobiphenyl $\mathbf{5 d}$; pyrrole $\mathbf{4 d}$ is not formed under these conditions (Table 4).

Table 4. Rearrangement of $N$-methylpyridinium salt 3d by $30 \% \mathrm{MeNH}_{2}$ solution in ethanol ${ }^{a}$ (Method A), 40\% aqueous solution of $\mathrm{MeNH}_{2}{ }^{b}$ (Method B), $40 \%$ aqueous solution of $\mathrm{Me}_{2} \mathrm{NH}^{c}$ (Method C) and $10 \%$ aqueous solution of $\mathrm{NaOH}^{d}$ (Method D)

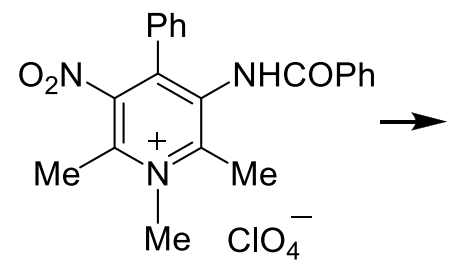

$3 d$<smiles>CC(=O)c1[nH]c(C)c([N+](=O)[O-])c1-c1ccccc1</smiles>

4d<smiles>CNc1cc(C)c(NC(=O)c2ccccc2)c(-c2ccccc2)c1[N+](=O)[O-]</smiles>

$5 d$

\begin{tabular}{lcc}
\hline & Nitropyrrole 4d & N-(methylamino)biphenyl 5d \\
\hline Method A & $51 \%$ & $5 \%$ \\
Method B & $19 \%$ & $45 \%$ \\
Method C & $16 \%$ & $54 \%$ \\
Method D & 0 & $60 \%$ \\
\hline
\end{tabular}

${ }^{a}$ Method A: $N$-methylpyridinium salt $(1 \mathrm{mmol}), 30 \% \mathrm{MeNH}_{2}$ solution in ethanol $(20 \mathrm{~mL}), 72 . \mathrm{h}$, rt. ${ }^{\mathrm{b}}$ Method B: $N$-methylpyridinium salt (1 mmol), $40 \%$ aqueous solution of $\mathrm{MeNH}_{2}(25 \mathrm{~mL}), 48$ h, rt. ${ }^{\mathrm{c}}$ Method C: $N$-methylpyridinium salt $(1 \mathrm{mmol}), 40 \%$ aqueous solution of $\mathrm{Me}_{2} \mathrm{NH}(25 \mathrm{~mL})$, $48 \mathrm{~h}$, rt. ${ }^{\mathrm{d}}$ Method D: $N$-methylpyridinium salt $(1 \mathrm{mmol})$, EtOH $(6 \mathrm{~mL}), 10 \%$ aqueous solution of $\mathrm{NaOH}(1.8 \mathrm{~mL}), 3 \mathrm{~h}, \mathrm{rt}$.

It is known that the basicity of methylamine is less in ethanol ( $\mathrm{p} K_{a}$ of conjugate acid is 9.58) than in water ( $\mathrm{p} K_{\mathrm{a}}$ is 10.66$) .{ }^{40,41}$ Therefore, the less basic ethanolic methylamine deprotonates only the more acidic NH proton of the benzamido group and this results in formation of pyrrole $\mathbf{4 d}$ (Scheme 2). The more basic methylamine and dimethylamine aqueous solutions $\left(\mathrm{p} K_{a} 10.73\right.$ ) deprotonate the $\mathrm{NH}$ group and remove proton from the methyl group of intermediate $\mathbf{F}$ that 
participates in intramolecular crotonic condensation. Cyclization of the dianion $\mathbf{F}$ occurs selectively with formation of the thermodynamically favorable methylaminobiphenyl $\mathbf{5 d}$ as the main product (Table 4 and Scheme 2). ${ }^{37,42}$
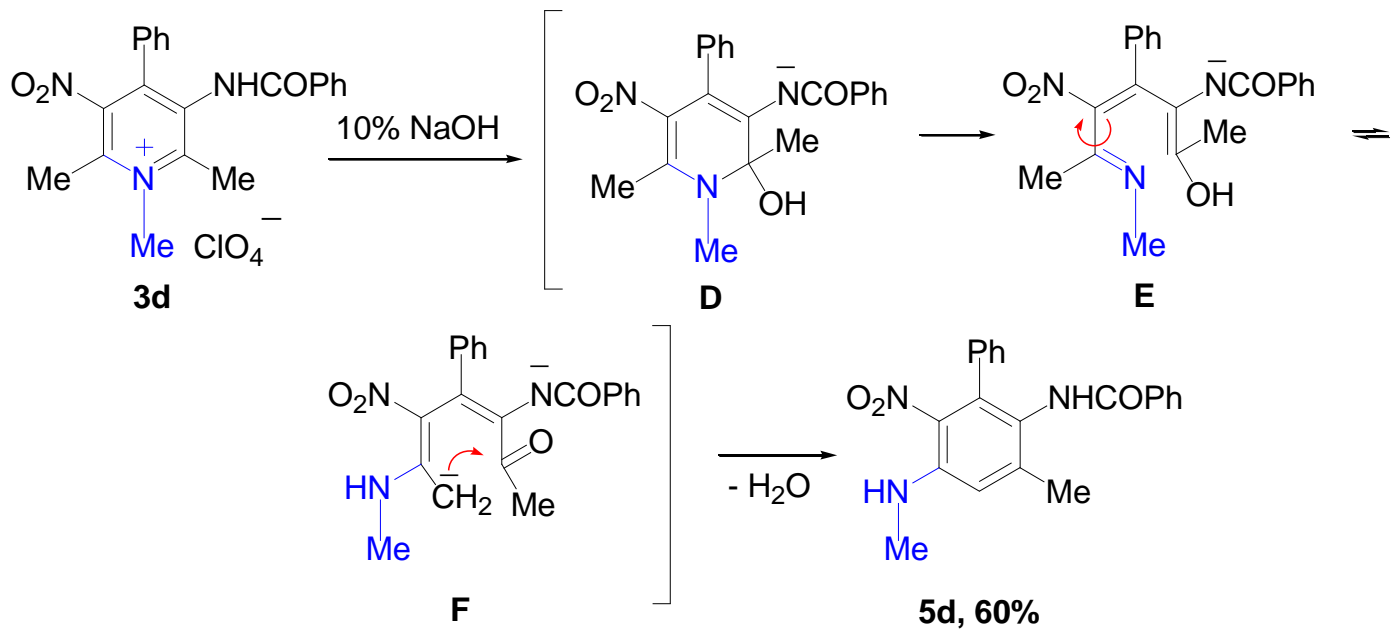

Scheme 2. Possible mechanism for the formation of $N$-(methylamino)biphenyl $\mathbf{5 d}$ by $10 \%$ aqueous $\mathrm{NaOH}$ solution (Method D).

\section{Conclusions}

A new approach to 2-acyl-4-nitropyrroles synthesis is developed and the optimum reaction conditions found. The rearrangement proceeds by breaking a $\mathrm{C}-\mathrm{N}$ bond in pyridine and recyclization with pyridine ring contraction. The source of the pyrrole nitrogen is the nitrogen atom of the exocyclic benzoylamino group of the pyridinium salt.

The rearrangement of 5-amino- $N$-methyl(aryl)isoquinolinium salts to 4-formylindoles can be the logical continuation and extension of this reaction.

\section{Experimental Section}

General. ${ }^{1} \mathrm{H}$ NMR spectra were recorded on a Bruker Avance DRX-400 (400 MHz) in $\mathrm{CDCl}_{3}$ and DMSO- $d_{6}$, internal standard was the residual protons of the solvent $\left(\mathrm{CDCl}_{3} \delta 7.25\right.$ and DMSO- $d_{6}$ $\delta 2.50 \mathrm{ppm}) .{ }^{13} \mathrm{C}$ NMR spectra were recorded on a Bruker DRX-400 (100 MHz) spectrometer with DMSO- $d_{6}(\delta \mathrm{C} 39.50 \mathrm{ppm})$ and $\mathrm{CDCl}_{3}(\delta \mathrm{C} 77.00 \mathrm{ppm})$ as internal standard. The IR spectra were obtained on a Simex FT-801 instrument with an attachment for a single broken internal reflection. Elemental analysis was carried out on a Perkin-Elmer CHN Analyzer. Column chromatography was carried out using Merck silica gel (60A, 0.060-0.200 mm). The reaction progress and purity of the synthesized compounds was monitored by TLC method on Silufol UV-254 plates. The 
reagents and solvents used in this work were obtained from Aldrich and Fluka and were used without further purification. The substrates of 3-aminopyridines 1a-e were prepared according to known procedures. ${ }^{39}$

General procedure for the synthesis of 3-(benzoylamino)-5-nitropyridines (2a-e). Benzoyl chloride $1.08 \mathrm{~g}$ (7.7 mmol) was added dropwise to solution of 3 -aminopyridine 1a-e $(7 \mathrm{mmol})$ in absolute pyridine $(5 \mathrm{~mL})$ at $0{ }^{\circ} \mathrm{C}$. The mixture was stirred for $10 \mathrm{~min}$ at $0{ }^{\circ} \mathrm{C}$ and then for $2 \mathrm{~h}$ at room temperature. After that, absolute ethanol $(1.5 \mathrm{~mL})$ was added to the mixture and it was stirred for $10 \mathrm{~min}$. The reaction mixture was diluted with cooled water and the precipitate was filtered. Pyridines 2a-e were recrystallized from $95 \%$ ethanol.

$\boldsymbol{N}$-(4,6-Dimethyl-5-nitropyridin-3-yl)benzamide (2a). Yield 92\%, colorless crystals, mp 213$215{ }^{\circ} \mathrm{C} .{ }^{1} \mathrm{H}$ NMR (400 MHz, DMSO-d 6 ): $\delta_{\mathrm{H}} 2.18$ (s, 3H, 4-Me), 2.49 (s, 3H, 6-Me), 7.51-7.67 (m, $3 \mathrm{H}, \mathrm{COPh}), 7.97-8.04(\mathrm{~m}, 2 \mathrm{H}, \mathrm{COPh}), 8.63(\mathrm{~s}, 1 \mathrm{H}, 2-\mathrm{H}), 10.38(\mathrm{~s}, 1 \mathrm{H}, \mathrm{NH}) . \mathrm{IR}\left(\mathrm{v} / \mathrm{cm}^{-1}\right): \mathrm{NH}$ 3440, $\mathrm{CO} 1700, \mathrm{NO}_{2}$ 1530, 1330. Calc. for $\mathrm{C}_{14} \mathrm{H}_{13} \mathrm{~N}_{3} \mathrm{O}_{3}$ : $\mathrm{C}$ 61.99; $\mathrm{H}$ 4.93; $\mathrm{N}$ 15.49. Found: $\mathrm{C}$ 62.39; H 5.09; N $15.30 \%$.

$\boldsymbol{N}$-(5-Nitro-2-phenylpyridin-3-yl)benzamide (2b). Yield 81\%, colorless crystals, mp 178-180 ${ }^{\circ} \mathrm{C} .{ }^{1} \mathrm{H}$ NMR (400 MHz, DMSO-d $)$ ): $\delta_{\mathrm{H}}$ 7.43-7.64 (m, 6H, Ph, COPh), 7.76-7.92 (m, 4H, Ph), 8.84 (s, 1H, 6-H), 9.34 (s, 1H, 4-H), 10.43 (s, 1H, NH). IR (v/cm $\left.{ }^{-1}\right)$ : NH 3430, CO 1705, $\mathrm{NO}_{2}$ 1540, 1350. Calc. for $\mathrm{C}_{18} \mathrm{H}_{13} \mathrm{~N}_{3} \mathrm{O}_{3}$ : C 67.71; H 4.10; N 13.16. Found: C 67.92; H 3.90; N $12.86 \%$. $\boldsymbol{N}$-(6-Methyl-5-nitro-2-phenylpyridin-3-yl)benzamide (2c). Yield 85\%, colorless crystals, mp 195-197 ${ }^{\circ} \mathrm{C} .{ }^{1} \mathrm{H}$ NMR (400 MHz, DMSO-d $)$ ): $\delta_{\mathrm{H}} 2.83$ (s, 3H, 6-Me), 7.43-7.61 (m, 6H, Ph, COPh), 7.72-7.89 (m, 4H, Ph), 8.66 (s, 1H, 4-H), 10.39 (s, 1H, NH). IR (v/cm $\left.{ }^{-1}\right):$ NH 3450, CO 1705, $\mathrm{NO}_{2}$ 1530, 1340. Calc. for $\mathrm{C}_{19} \mathrm{H}_{15} \mathrm{~N}_{3} \mathrm{O}_{3}: \mathrm{C} 68.46 ; \mathrm{H} 4.54 ; \mathrm{N} 12.61$. Found: C 68.18; H 4.47; N $12.75 \%$. $\boldsymbol{N}$-(2,6-Dimethyl-5-nitro-4-phenylpyridin-3-yl)benzamide (2d). Yield 82\%, colorless crystals, mp 230-232 ${ }^{\circ} \mathrm{C} .{ }^{1} \mathrm{H}$ NMR (400 MHz, DMSO-d 6 ): $\delta_{\mathrm{H}} 2.47$ (s, 3H, 2-Me), 2.52 (s, 3H, 6-Me), 7.197.25 (m, 2H, Ph), 7.35-7.45 (m, 5H, Ph, COPh), 7.48-7.54 (m, 1H, COPh), 7.62-7.67 (m, 2H, $\mathrm{COPh}), 10.01(\mathrm{~s}, 1 \mathrm{H}, \mathrm{NH}) . \mathrm{IR}\left(\mathrm{v} / \mathrm{cm}^{-1}\right)$ : $\mathrm{NH} 3430, \mathrm{CO} 1710, \mathrm{NO}_{2}$ 1540, 1350. Calc. for $\mathrm{C}_{20} \mathrm{H}_{17} \mathrm{~N}_{3} \mathrm{O}_{3}$ : C 69.15; H 4.93; N 12.10. Found: C 69.27; H 5.03; N $12.23 \%$.

$\boldsymbol{N}$-(6-Methyl-5-nitro-2,4-diphenylpyridin-3-yl)benzamide (2e). Yield 95\%, colorless crystals, mp 320-324 ${ }^{\circ} \mathrm{C} .1 \mathrm{H} \mathrm{NMR}\left(400 \mathrm{MHz}, \mathrm{DMSO}-\mathrm{d}_{6}\right)$ : $\delta \mathrm{H} 2.64$ (s, 3H, 6-Me), 7.29-7.48 (m, 13H, 2,4$\mathrm{Ph}, \mathrm{COPh}), 7.70-7.76(\mathrm{~m}, 2 \mathrm{H}, 2-\mathrm{Ph}), 9.93$ (s, 1H, NH). IR (v/cm $\left.{ }^{-1}\right)$ : NH 3440, CO 1705, $\mathrm{NO}_{2}$ 1540, 1340. Calc. for $\mathrm{C}_{25} \mathrm{H}_{19} \mathrm{~N}_{3} \mathrm{O}_{3}$ : C 73.34; H 4.68; N 10.26. Found: C 73.28; H 4.65; N $10.33 \%$.

General procedure for the synthesis of $N$-methylpyridinium salts $(3 a, b, d, e)$. The mixture of pyridine $\mathbf{2 a}, \mathbf{b}, \mathbf{d}, \mathbf{e}(5 \mathrm{mmol})$ and $\mathrm{Me}_{2} \mathrm{SO}_{4} 1.4 \mathrm{~mL}(15 \mathrm{mmol})$ was heated (the heating conditions specified below). Then, mixture was chilled and washed with dry ether $(3 \times 10 \mathrm{~mL})$ and the ether was removed by decantation. All the residues except non-hygroscopic 3-(benzoylamino)pyridinium methylsulfate 3a were dissolved in $\mathrm{H}_{2} \mathrm{O}(5 \mathrm{~mL})$ and saturated aqueous solution of $\mathrm{NaClO}_{4}(5.3 \mathrm{mmol})$ was added. Finally, the pyridinium salts $\mathbf{3 a}, \mathbf{b}, \mathbf{d}, \mathbf{e}$ were filtered, dried and recrystallized from ethanol.

5-(Benzoylamino)-1,2,4-trimethyl-3-nitropyridinium methyl sulfate (3a). Conditions $4 \mathrm{~h}$ and $80{ }^{\circ} \mathrm{C}$, yield $89 \%$, colorless crystals, mp 210-211 ${ }^{\circ} \mathrm{C} .{ }^{1} \mathrm{H}$ NMR (400 MHz, DMSO-d 6$): \delta_{\mathrm{H}} 2.50(\mathrm{~s}$, 
3H, 4-Me), 2.71 (s, 3H, 6-Me), 3.37 (s, 3H, $\mathrm{MeSO}_{4}$ ), 4.34 (s, 3H, NMe), 7.60-7.74 (m, 3H, COPh), 8.03-8.08 (m, 2H, COPh), 9.49 (s, 1H, 2-H) 10.83 (s, 1H, NH). Calc. for $\mathrm{C}_{16} \mathrm{H}_{19} \mathrm{~N}_{3} \mathrm{O}_{7} \mathrm{~S}$ : C 48.36; H 4.82; N 10.57. Found: C 48.06; H 4.78; N $11.13 \%$.

3-(Benzoylamino)-1-methyl-5-nitro-2-phenylpyridinium perchlorate $(3 \mathrm{~b})$. Conditions $5 \mathrm{~h}$ and $100{ }^{\circ} \mathrm{C}$, yield $92 \%$, colorless crystals, mp 220-221 ${ }^{\circ} \mathrm{C} .{ }^{1} \mathrm{H}$ NMR $\left(400 \mathrm{MHz}, \mathrm{DMSO}-\mathrm{d}_{6}\right): \delta_{\mathrm{H}} 4.18(\mathrm{~s}$, 3H, NMe), 7.42-7.52 (m, 2H, Ph), 7.57-7.73 (m, 8H, Ph, COPh), 9.69 (d, 1H, 4-H, ${ }^{4} J 2.5$ ), 10.25 (d, $1 \mathrm{H}, 6-\mathrm{H},{ }^{4} J$ 2.5), 10.42 (s, 1H, NH). Calc. for $\mathrm{C}_{19} \mathrm{H}_{16} \mathrm{ClN}_{3} \mathrm{O}_{7}$ : C 52.61; $\mathrm{H} 3.72 ; \mathrm{N} 9.69$. Found: C 52.39; H 3.67; N $9.83 \%$.

3-(Benzoylamino)-1,2,6-trimethyl-5-nitro-4-phenylpyridinium perchlorate (3d). Conditions $48 \mathrm{~h}$ and $80{ }^{\circ} \mathrm{C}$, yield $85 \%$, colorless crystals, mp 168-170 ${ }^{\circ} \mathrm{C} .{ }^{1} \mathrm{H}$ NMR (400 MHz, DMSO-d 6 ): $\delta_{H} 2.83(\mathrm{~s}, 3 \mathrm{H}, 2-\mathrm{Me}), 2.85$ (s, 3H, 6-Me), 4.29 (s, 3H, NMe), 7.15-7.70 (m, 10H, Ph, COPh), 10.66 (s, $1 \mathrm{H}, \mathrm{NH}$ ). Calc. for $\mathrm{C}_{21} \mathrm{H}_{20} \mathrm{ClN}_{3} \mathrm{O}_{7}$ : C 54.61; H 4.36; N 9.10. Found: C 54.82; H 4.40; N $9.24 \%$.

3-(Benzoylamino)-1,6-dimethyl-5-nitro-2,4-diphenylpyridinium perchlorate (3e). Conditions $96 \mathrm{~h}$ and $100{ }^{\circ} \mathrm{C}$, yield $70 \%$, colorless crystals, mp 163-165 ${ }^{\circ} \mathrm{C} .{ }^{1} \mathrm{H}$ NMR (400 MHz, DMSO-d 6 ): $\delta_{\mathrm{H}} 2.86$ (s, 3H, 6-Me), 3.96 (s, 3H, NMe), 7.15-7.65 (m, 15H, 2,4-Ph, COPh), 10.33 (s, 1H, NH). Calc. for $\mathrm{C}_{26} \mathrm{H}_{22} \mathrm{ClN}_{3} \mathrm{O}_{7}$ : C 59.60; H 4.23; N 8.02. Found: C 59.55; H 4.29; $\mathrm{N} 7.98 \%$.

3-(Benzoylamino)-1,6-dimethyl-5-nitro-2-phenylpyridinium fluorosulfonate $\mathbf{( 3 c )}$. The solution of $\mathrm{MeSO}_{3} \mathrm{~F}(15 \mathrm{~mol})$ in chlorobenzene $(3 \mathrm{~mL})$ was added dropwise to stirred solution of pyridine $2 \mathrm{c}(5 \mathrm{mmol})$ in chlorobenzene $(15 \mathrm{~mL})$ at $0{ }^{\circ} \mathrm{C}$. The mixture was stirred for $30 \mathrm{~min}$ at 0 ${ }^{\circ} \mathrm{C}$ and than, for 5 days at room temperature. After that, the mixture was diluted with diethyl ether. The precipitate was filtered and recrystallized from ethanol. The colorless crystals were obtained in 90\% yield, mp 209-210 ${ }^{\circ} \mathrm{C} .{ }^{1} \mathrm{H}$ NMR (400 MHz, DMSO-d 6 ): $\delta_{H} 2.94$ (c, 3H, 6-Me), 3.99 (s, 3H, $\mathrm{NMe}$, 7.37-7.46 (m, 2H, Ph), 7.50-7.68 (m, 8H, Ph, COPh), 9.38 (s, 1H, 4-H), 10.16 (s, 1H, NH). Calc. for $\mathrm{C}_{20} \mathrm{H}_{18} \mathrm{FN}_{3} \mathrm{O}_{6} \mathrm{~S}$ : C 53.69; H 4.05; N 9.39. Found: C 53.72; H 3.97; N $9.33 \%$.

Preparation of 3-nitropyrroles (4a-e) (Method A). The $30 \%$ solution of the methylamine in ethanol $(20 \mathrm{~mL})$ was added to a solution of the corresponding salt $\mathbf{3 a}-\mathbf{e}(1 \mathrm{mmol})$ in DMF $(1 \mathrm{~mL})$ and the mixture stirred for $72 \mathrm{~h}$ at room temperature. The solvent was evaporated under reduced pressure, than, the separation of nitropyrroles 4a-e and nitroanilines 5a-e was carried out by column chromatography on silica gel. The products were recrystallized from ethanol.

3,5-Dimethyl-4-nitro-1H-pyrrole-2-carbaldehyde (4a) and $N$-[2-methyl-4-(methylamino)-3nitrophenyl]benzamide (5a). Eluent $\mathrm{CCl}_{4}-$ ethyl acetate, 1:1. For 4a: yield $71 \%$, colorless crystals, mp $219-220{ }^{\circ} \mathrm{C}\left(1 \mathrm{it}^{43} . \mathrm{mp} 215-218{ }^{\circ} \mathrm{C}\right) .{ }^{1} \mathrm{H}$ NMR $\left(400 \mathrm{MHz}, \mathrm{DMSO}-\mathrm{d}_{6}\right): \delta_{\mathrm{H}} 2.54(\mathrm{~s}, 3 \mathrm{H}$, 5-Me), 2.55 (s, 3H, 3-Me), 9.72 (s, 1H, CHO), 12.77 (br.s, 1H, NH). ${ }^{13} \mathrm{C}$ NMR (100 MHz, DMSO$\left.\mathrm{d}_{6}\right): \delta_{\mathrm{C}} 9.60,13.40,126.42,126.91,132.87,138.82,178.88$. IR $\left(\mathrm{v} / \mathrm{cm}^{-1}\right)$ : NH 3415, CO 1655, $\mathrm{NO}_{2}$ 1530, 1360. Calc. for $\mathrm{C}_{7} \mathrm{H}_{8} \mathrm{~N}_{2} \mathrm{O}_{3}$ : C 50.00; H 4.80; N 16.66. Found : C 49.89; H 4.79; N $16.59 \%$. For 5a: yield 3\%, orange crystal, mp 264-265 ${ }^{\circ} \mathrm{C}$. Mass spectrum, $m / z$ ( $\left.I_{\text {rel }}, \%\right): 285[\mathrm{M}]^{+\bullet}(52)$, $105[\mathrm{PhCO}]^{+}(100), 77[\mathrm{Ph}]^{+}(36)$.

(4-Nitro-1H-pyrrol-2-yl)(phenyl)methanone (4b). Eluent $\mathrm{CHCl}_{3}$ - ethyl acetate, 9:1. Yield 51\%, colorless crystals, mp 213-215 ${ }^{\circ} \mathrm{C} .{ }^{1} \mathrm{H}$ NMR (400 MHz, $\left.\mathrm{CDCl}_{3}\right): \delta_{\mathrm{H}} 7.39-7.42(\mathrm{~m}, 1 \mathrm{H}, 3-\mathrm{H}), 7.50-$ 
7.59 (m, 2H, COPh), 7.62-7.70 (m, 1H, 5-H), 7.88-7.97 (m, 3H, COPh), 10.02 (br.s, 1H, NH). ${ }^{13} \mathrm{C} \mathrm{NMR}\left(100 \mathrm{MHz} \mathrm{CDCl}_{3}\right): \delta_{\mathrm{C}} 112.70,128.85,129.00,129.57,132.31,133.29,135.83,136.34$, 189.27. IR $\left(v / \mathrm{cm}^{-1}\right)$ : $\mathrm{NH} 3415, \mathrm{CO} 1640, \mathrm{NO}_{2} 1520,1330$. Calc. for $\mathrm{C}_{11} \mathrm{H}_{8} \mathrm{~N}_{2} \mathrm{O}_{3}: \mathrm{C} 61.11 ; \mathrm{H} 3.73$; N 12.96. Found: C 61.07; H 3.80; N $12.94 \%$.

Methyl[(1Z)-(5-methyl-4-nitro-1H-pyrrol-2-yl)(phenyl)methylene]amine (4c) and $N$-[5(methylamino)-4-nitrobiphenyl-2-yl]benzamide (5c). Eluent $\mathrm{CCl}_{4}$ - ethyl acetate, 1:1. For 4c: yield $65 \%$, colorless crystals, mp 201-202 ${ }^{\circ} \mathrm{C} .{ }^{1} \mathrm{H} \mathrm{NMR}\left(400 \mathrm{MHz}, \mathrm{CDCl}_{3}\right): \delta_{\mathrm{H}} 2.65$ (s, 3H, 5-Me), 3.21 (s, 3H, NMe), 6.48 (s, 1H, 3-H), 7.21-7.28 (m, 2H, Ph), 7.43-7.55 (m, 3H, Ph), 8.69 (br.s, $1 \mathrm{H}, \mathrm{NH}) .{ }^{13} \mathrm{C} \mathrm{NMR}\left(100 \mathrm{MHz}, \mathrm{CDCl}_{3}\right): \delta_{\mathrm{C}} 13.83,39.42,111.17,127.71,128.71,129.23,129.64$, 133.09, 134.62, 135.92, 161.68. IR $\left(v / \mathrm{cm}^{-1}\right)$ : NH 3415, $\mathrm{NO}_{2} 1525,1320$. Calc. for $\mathrm{C}_{13} \mathrm{H}_{13} \mathrm{~N}_{3} \mathrm{O}_{2}: \mathrm{C}$ 64.19; H 5.39; N 17.27. Found: C 64.24; H 5.28; N 17.10 \%. For 5c: yield 5\%, orange crystal, mp 191-192 ${ }^{\circ} \mathrm{C} .{ }^{1} \mathrm{H}$ NMR (400 MHz, DMSO-d 6 ): $\delta_{H} 3.03$ (d, 3H, NHMe, $J 5.2 \mathrm{~Hz}$ ), , 6.91 (s, 1H, 3$\mathrm{H}), 7.32-7.58$ (m, 8H, Ph, COPh), 7.65-7.80 (m, 2H, COPh), 8.14 (s, 1H, 6-H), 8.24 (q, 1H, $\underline{\mathrm{NHMe}}, J 5.2 \mathrm{~Hz}), 9.80(\mathrm{~s}, 1 \mathrm{H}, \mathrm{NH}) .{ }^{13} \mathrm{C} \mathrm{NMR}\left(100 \mathrm{MHz}, \mathrm{DMSO}-\mathrm{d}_{6}\right): \delta_{\mathrm{C}} 29.74,115.11,122.79$, $125.57,127.35,128.19,128.21,128.28,128.38,129.28,131.41,134.22,137.85,144.48,147.61$, 166.18. IR $\left(v / \mathrm{cm}^{-1}\right)$ : $\mathrm{NH} 3430,3350, \mathrm{CO} 1670, \mathrm{NO}_{2} 1535,1340$. Calc. for $\mathrm{C}_{20} \mathrm{H}_{17} \mathrm{~N}_{3} \mathrm{O}_{3}: \mathrm{C} 69.15$; H 4.93; N 12.10. Found: C 69.31; H 4.88; N $12.24 \%$.

1-(5-Methyl-4-nitro-3-phenyl-1H-pyrrol-2-yl)ethanone (4d) and $\boldsymbol{N}$-[3-methyl-5-(methylamino)-6-nitrobiphenyl-2-yl]benzamide (5d). $\mathrm{CHCl}_{3}$ - ethyl acetate, 9:1. For 4d: yield 51\%, colorless crystals, mp 215-217 ${ }^{\circ} \mathrm{C} .{ }^{1} \mathrm{H}$ NMR $\left(400 \mathrm{MHz}, \mathrm{CDCl}_{3}\right): \delta_{\mathrm{H}} 1.87$ (s, 3H, 5-Me), $2.73(\mathrm{~s}$, 3H, COMe), 7.30-7.35 (m, 2H, Ph), 7.43-7.50 (m, 3H, Ph), 10.56 (br.s, 1H, NH). ${ }^{13} \mathrm{C}$ NMR (100 $\left.\mathrm{MHz}, \mathrm{CDCl}_{3}\right): \delta_{\mathrm{C}} 14.31,27.65,119.61,126.53,127.64,128.42,128.50,129.56,132.34,135.98$, 189.33. IR $\left(v / \mathrm{cm}^{-1}\right)$ : $\mathrm{NH} 3400, \mathrm{CO} 1645, \mathrm{NO}_{2} 1525,1350$. Calc. for $\mathrm{C}_{13} \mathrm{H}_{12} \mathrm{~N}_{2} \mathrm{O}_{3}$ : C 63.93; $\mathrm{H} 4.95$; N 11.47. Found: C 64.02; H 5.01; N $11.56 \%$. For 5d: yield 5\%, orange crystal, mp 258-260 ${ }^{\circ} \mathrm{C}$. ${ }^{1} \mathrm{H}$ NMR (400 MHz, DMSO-d 6 ): $\delta_{H} 2.31$ (s, 3H, 3-Me), 2.82 (d, 3H, NHMe, J 4.2 Hz), 6.37 (q, 1H, NHMe, J 4.2 Hz), 6.79 (s, 1H, 4-H), 6.92-7.01 (m, 1H, Ph), 7.13-7.33 (m, 9H, Ph, COPh), $10.00(\mathrm{~s}, 1 \mathrm{H}, \mathrm{NH}) .{ }^{13} \mathrm{C}$ NMR $\left(100 \mathrm{MHz}, \mathrm{DMSO}-\mathrm{d}_{6}\right): \delta_{\mathrm{C}} 18.68,29.89,112.79,123.13,127.16$, $127.51,127.73,128.16,128.22$, 129.89, 131.24, 134.35, 134.67, 135.39, 141.15, 142.38, 166.51. IR $\left(v / \mathrm{cm}^{-1}\right)$ : $\mathrm{NH} 3430,3330, \mathrm{CO} 1650, \mathrm{NO}_{2}$ 1520, 1360. Calc. for $\mathrm{C}_{21} \mathrm{H}_{19} \mathrm{~N}_{3} \mathrm{O}_{3} \%: \mathrm{C} 69.79 ; \mathrm{H}$ 5.30; N 11.63. Found \%: C 69.73; H 5.31; N 11.54.

(5-Methyl-4-nitro-3-phenyl-1H-pyrrol-2-yl)(phenyl)methanone $(4 \mathrm{e})$ and $\mathrm{N}$-[5'-(methylamino)-4'-nitro-1,1':3',1'"-terphenyl-2'-yl]benzamide (5e). $\mathrm{CHCl}_{3}$ - ethyl acetate, 9:1. For 4e: yield $0 \%$, not determined. For 5e: yield $15 \%$, orange crystals, mp $280-283{ }^{\circ} \mathrm{C} .{ }^{1} \mathrm{H} \mathrm{NMR}(400 \mathrm{MHz}$, DMSO-d 6 ): $\delta_{H} 2.85$ (d, 3H, NHMe, J $\left.4.0 \mathrm{~Hz}\right), 6.35$ (q, 1H, HMe, J $\left.4.0 \mathrm{~Hz}\right), 6.78$ (s, 1H, 6-H), 7.20-7.39 (m, 13H, 1,3-Ph, COPh), 7.47-7.54 (m, 2H, COPh), 9.41 (s, 1H, NH). ${ }^{13} \mathrm{C}$ NMR (100 MHz, DMSO-d 6 ): $\delta_{\mathrm{C}} 29.62,112.76,121.54,125.08,126.64,127.38,127.43,127.64,127.73$, 128.04. 128.38, 130.60, 134.59, 134.80, 136.03, 138.17, 138.72, 140.66, 145.34, 166.85. IR $\left(v / \mathrm{cm}^{-1}\right)$ : NH 3420, 3310, CO 1630, $\mathrm{NO}_{2}$ 1530, 1340. Calc. for $\mathrm{C}_{26} \mathrm{H}_{21} \mathrm{~N}_{3} \mathrm{O}_{3}: \mathrm{C}$ 73.74; $\mathrm{H}$ 5.00; $\mathrm{N}$ 9.92. Found: C 73.82; H 5.08; N $10.06 \%$. 
Preparation of 3-nitropyrrole 4d and $\boldsymbol{N}$-(methylamino)biphenyl 5d (Method B).The 40\% aqueous solution of the methylamine $(20 \mathrm{~mL})$ was added to salt $\mathbf{3 d}(1 \mathrm{mmol})$ and the mixture stirred for $48 \mathrm{~h}$ at room temperature. The precipitated solid of nitroaniline $\mathbf{5 d}$ was filtered off. The filtrate was neutralized with $5 \%$ hydrochloric acid solution; the precipitated solid of nitropyrrole 4d was also filtered off. The products were purified by column chromatography $\left(\mathrm{CHCl}_{3}-\right.$ ethyl acetate, 9:1) and recrystallized from ethanol. For nitropyrrole 4d: yield 19\%, colorless crystal, mp 215-217 ${ }^{\circ} \mathrm{C}$. For nitroaniline 5d: yield $45 \%$, orange crystals, mp $258-260^{\circ} \mathrm{C}$.

Preparation of 3-nitropyrrole $4 d$ and $\boldsymbol{N}$-(methylamino)biphenyl 5d (Method C). The 40\% aqueous solution of dimethylamine $(20 \mathrm{~mL})$ was added to the solution of salt $\mathbf{3 d}(1 \mathrm{mmol})$ in DMF $(1 \mathrm{~mL})$ than, the mixture stirred for $48 \mathrm{~h}$ at room temperature. The precipitated solid of nitroaniline 5d was filtered off. The filtrate was neutralized with $5 \%$ hydrochloric acid solution; the precipitated solid of nitropyrrole $\mathbf{4 d}$ was also filtered off. The products were purified by column chromatography $\left(\mathrm{CHCl}_{3}\right.$ - ethyl acetate, 9:1) and recrystallized from ethanol. For nitropyrrole $\mathbf{4 d}$ : yield $16 \%$, colorless crystal, mp $215-217{ }^{\circ} \mathrm{C}$. For nitroaniline 5d: yield 54\%, orange crystals, mp 258-260 ${ }^{\circ} \mathrm{C}$.

Preparation of $\boldsymbol{N}$-(methylamino)biphenyl 5d (Method D). A mixture of salt $3 d$ (1 mmol) in ethanol $(4 \mathrm{~mL})$ and $10 \%$ solution of sodium hydroxide in ethanol $(2 \mathrm{ml})$ was stirred for $24 \mathrm{~h}$ at room temperature. The precipitated solid of nitroaniline $\mathbf{5} \mathbf{d}$ was filtered off. The products were purified by column chromatography $\left(\mathrm{CHCl}_{3}\right.$ - ethyl acetate, 9:1) and recrystallized from ethanol. For nitroaniline 5d: yield $60 \%$, orange crystals, mp $258-260{ }^{\circ} \mathrm{C}$.

\section{Supplementary Material}

The original data of NMR spectra of all new compounds are supplied.

\section{Acknowledgements}

This work has been financially supported by the Russian Foundation of Basic Research (grant 0703-00783-a).

\section{References}

1. van der Plas, H. C. Ring Transformations of Heterocycles. In Organic Chemistry A Series of Monographs; Blomquist, A. T.; Wasserman, H., Eds.; Academic Press: London, New York, 1973; Vol. 2, 352 p. 
2. Wentrup, C. Carbenes and Nitrenes in Heterocyclic Chemistry: Intramolecular Reactions. In Advances in Heterocyclic Chemistry; Katritzky, A. R.; Boulton, A. J. Eds.; Academic Press: New York, 1981; Vol. 28, pp. 231-361. http://dx.doi.org/10.1016/S0065-2725(08)60044-6

3. Bean, G. P. The Synthesis of 1 H-Pyrroles. In Chemistry of Heterocyclic Compounds: A Series of Monographs; Jones, R. A., Ed.; John Wiley \& Sons, Ltd.: New York, 1990; Vol. 48, Part 1, pp. 105-294.

http://dx.doi.org/10.1002/9780470187326.ch2

4. Den Hertog, H. J.; Martens, R. J.; van der Plas, H. C.; Bon, J. Tetrahedron Lett. 1966, 7, 43254326. http://dx.doi.org/10.1016/S0040-4039(00)76059-X

5. van der Lans, H. N. M.; den Hertog, H. J.; van Veldhuizen, A. Tetrahedron Lett. 1971, 12, 1875-1878.

http://dx.doi.org/10.1016/S0040-4039(01)87486-4

6. Roelfsema, W. A. Aminering van Hydroxyderivaten van Halogeenazahetarenen. Ph.D. Dissertation, Wageningen: Veenman, 1972. http://library.wur.nl/WebQuery/wurpubs/421729

7. Roelfsema, W. A.; den Hertog, H. J. Tetrahedron Lett. 1967, 8, 5089-5090. http://dx.doi.org/10.1016/S0040-4039(01)89921-4

8. Crow, W. D.; Wentrup, C. Chem. Commun. (London). 1968, 1082-1083. http://dx.doi.org/10.1039/C19680001082

9. Wentrup, C.; Crow, W. D. Tetrahedron. 1970, 26, 3965-3981. http://dx.doi.org/10.1016/S0040-4020(01)93037-6

10. Wentrup, C.; Winter, H.-W. J. Am.Chem. Soc. 1980, 102, 6159-6161. http://dx.doi.org/10.1021/ja00539a039

11. McCluskey, A.; Wentrup, C. J. Org. Chem. 2008, 73, 6265-6267. http://dx.doi.org/10.1021/jo800899t

12. Wentrup, C.; Lan, N. M.; Lukosch, A.; Bednarek, P.; Kvaskoff, D. Beilstein J. Org. Chem. 2013, 9, 743-753. http://dx.doi.org/10.3762/bjoc.9.84

13. Wentrup, C. Acc. Chem. Res. 2011, 44, 393-404. http://dx.doi.org/10.1021/ar700198z

14. Abramovitch, R. A. J. Org. Chem. 1973, 38, 173-174. http://dx.doi.org/10.1021/jo00941a045

15. Abramovitch, R. A.; Cue, B. W., Jr. J. Am. Chem. Soc. 1976, 98, 1478-1486. http://dx.doi.org/10.1021/ja00422a034

16. Streith, J.; Sigwalt, C. Tetrahedron Lett. 1966, 7, 1347-1350. http://dx.doi.org/10.1016/S0040-4039(01)99720-5

17. Streith, J.; Darrah, H. K.; Weil, M. Tetrahedron Lett. 1966, 7, 5555-5562. http://dx.doi.org/10.1016/S0040-4039(00)70140-7 
18. Alkaitis, A.; Calvin. M. Chem. Commun. (London). 1968, 292-294. http://dx.doi.org/10.1039/C19680000292

19. Kumler, P. L.; Buchardt, O. Chem. Commun. (London), 1968, 1321-1323. http://dx.doi.org/10.1039/C19680001321

20. Spence, G. G.; Curtis, E.; Taylor, E. C.; Buchardt, O. Chem. Rev. 1970, 70, 231-265. http://dx.doi.org/10.1021/cr60264a003

21. Bellamy, F.; Martz, P.; Streith, J. Heterocycles. 1975, 3, 395-400. http://dx.doi.org/10.3987/R-1975-05-0395

22. Ishikawa, M.; Kaneko, C.; Yokoe, I.; Yamada, S. Tetrahedron. 1969, 25, 295-300. http://dx.doi.org/10.1016/S0040-4020(01)82624-7

23. Nesvadba, P.; Kuthan, J. Tetrahedron Lett. 1980, 21, 3727-3728. http://dx.doi.org/10.1016/S0040-4039(00)78758-2

24. Nesvadba, P.; Kuthan, J. Coll. Czech. Chem. Commun. 1982, 47, 1494-1502. http://dx.doi.org/10.1135/cccc19821494

25. Han, X.; Li, C.; Mosher, M. D.; Rider, K. C.; Zhou, P.; Crawford, R. L.; Fusco, W.; Paszczynski, A.; Natale, N. R. Bioorg. Med. Chem. 2009, 17, 1671-1680. http://dx.doi.org/10.1016/j.bmc.2008.12.056

26. Gómez, M. V.; Aranda, A. I.; Moreno, A.; Cossío, F. P.; de Cózar, A.; Díaz-Ortiz, Á.; de la Hoz, A.; Prieto, P. Tetrahedron. 2009, 65, 5328-5336. http://dx.doi.org/10.1016/j.tet.2009.04.065

27. Zhang, P.; Egholm, M.; Paul; Pingle, N. M.; Bergstrom, D. E. Methods. 2001, 23, 132-140. http://dx.doi.org/10.1006/meth.2000.1114

28. Loakes, D.; Hill, F.; Brown, D. M.; Ball, S.; Reeve, M. A.; Robinson, P. S. Nucleosides Nucleotides 1999, 18, 2685-2695. http://dx.doi.org/10.1080/07328319908044634

29. Ding, X.-B.; Brimble, M. A.; Furkert, D. P. Org. Biomol. Chem. 2016, 14, 5390-5401. http://dx.doi.org/10.1039/C5OB02599K

30. Garkushenko, A. K.; Sagitullina, G. P. Chem. Heterocycl. Comp. Int. Ed. 2011, 47, 1189-1205. http://dx.doi.org/10.1007/s10593-012-0894-5

31. Estevez, V.; Villacampa, M.; Menendez, J. C. Chem. Soc. Rev. 2014, 43, 4633-4657. http://dx.doi.org/10.1039/C3CS60015G

32. Regina, G. L.; Bai, R.; Coluccia, A.; Famiglini, V.; Pelliccia, S.; Passacantilli, S.; Mazzoccoli, C.; Ruggieri, V.; Sisinni, L.; Bolognesi, A.; Rensen, W. M.; Miele, A.; Nalli, M.; Alfonsi. R.; Marcotullio, L. D.; Gulino, A.; Brancale, A.; Novellino, E.; Dondio, G.; Vultaggio, S.; Varasi, M.; Mercurio, C.; Hamel, E.; Lavia, P.; Silvestri, R. J. Med. Chem. 2014, 57, 6531-6552. http://dx.doi.org/10.1021/jm500561a

33. Fan, H.; Peng, J.; Hamann, M. T.; Hu, J.-F. Chem. Rev. 2008, 108, 264-287. http://dx.doi.org/10.1021/cr078199m

34. Gholap, S. S. Eur. J. Med Chem. 2016. 110, 13-31. http://dx.doi.org/10.1016/j.ejmech.2015.12.017 
35. Schnekenburger, J.; Heber, D. Tetrahedron 1974, 30, 4055-4057.

http://dx.doi.org/10.1016/S0040-4020(01)97383-1

36. Blanch, J. H.; Fretheim, K. J. Chem. Soc. (C) 1971, 1892-1895. http://dx.doi.org/10.1039/J39710001892

37. Kost, A. N.; Gromov, S. P.; Sagitullin, R. S. Tetrahedron 1981, 37, 3423-3454. http://dx.doi.org/10.1016/S0040-4020(01)98858-1

38. Shkil, G. P.; Sagitullin, R. S. Tetrahedron Lett. 1993, 34, 5967-5968. http://dx.doi.org/10.1016/S0040-4039(00)73828-7

39. Sagitullina, G. P.; Garkushenko, A. K.; Glyzdinskaya, L. V.; Uldashev, F. A.; Vorontsova, M. A.; Sagitullin, R. S. Chem. Heterocycl. Comp. Int. Ed. 2010, 46, 1255-1261. http://dx.doi.org/10.1007/s10593-011-0660-0

40. Gutbezahl, B.; Grunwald, E. J. Am. Chem. Soc. 1953, 75, 559-565. http://dx.doi.org/10.1021/ja01099a014

41. Bel'skii, V. E.; Kudryavtseva, L. A.; Derstuganova, K. A.; Teitel'baum, A. B.; Ivanov, B. E. Bull. Acad. Sci. USSR, Div. Chem. Sci., Int. Ed. 1981, 30, 736-738. http://dx.doi.org/10.1007/BF00955273

42. Sagitullina, G. P.; Garkushenko, A. K.; Poendaev, N. V.; Vorontsova, M. A.; Sagitullin, R. S. Chem. Heterocycl. Comp., Int. Ed. 2011, 47, 470-481. http://dx.doi.org/10.1007/s10593-011-0783-3

43. Clezy, P. S.; Liepa, A. J.; Webb, N. W. Austr. J. Chem. 1972, 25, 2687-2700. http://dx.doi.org/10.1071/CH9722687 